\title{
Reflection on Give Play to Service Function of Colleges and Universities and Promoting Regional Party Construction
}

\author{
Fangyu Li \\ Leshan Normal University, Leshan, 614000, China
}

\begin{abstract}
Colleges and universities are typical representatives of regional organizations for regional party construction as well as supporting strength for promotion of regional party construction. Based on giving play to the service function of colleges and universities and promoting new needs of regional party construction, the author begins with the definition of regional party construction in colleges and universities, analyzes development tendency of regional party construction in colleges and universities, states principles for regional party construction in colleges and universities, and proposes approaches for promotion of regional party construction as well as guarantee and other work measures.
\end{abstract}

Key words: colleges and universities, service function, regional party construction, scientific development

Regional party construction is a new exploration for grass-roots party construction mode by the Chinese Communist Party to make positive response to maladjustment between traditional "unit system party construction” and structural transformation of economic society as well as important content of perfecting the grass-roots party organization system. Based on reasonable regional division, regional party construction is a new pattern of grass-roots party construction works formed by participation of all party members in the region, with street (community) party organization as the core and regional organization party organization as the support. The main function of regional party construction is to consolidate ruling, promote development, serve the masses, accumulate public feeling and promote harmony. Regional party construction should be promoted from various aspects, including forming party construction combo, forging public service platform, reinforcing regional cultural construction and improving regional governance capacity.

I. Tendency of Regional Party Construction in Colleges and Universities

In October, 2004, the Communist Party of China proposed for the first time job requirements for the structure of regional party construction. Shanghai, Guangdong and other places positively developed exploration for and practice of regional party construction. The $18^{\text {th }}$ CPC National Congress made a decision to comprehensively improve the scientific level of party construction. In May, 2014, the Central Committee of the CPC issued Opinions on Strengthening the Construction of Grass-roots Service-oriented Party Organization, and definitely proposed that 
“for the implementation of regional party construction, street \& community party organization and unit party organization in the area under administration can jointly construct a regional party organization or rely on residential area, business district, development area and others to construct a regional party organization, reasonably divide the service gridding and construct the gridding service team, so as to realize the objective of the access to party organization to serve the masses at various places”. Thus, it is clearer for functional orientation and organizational pattern of regional party construction. Its practice is even comprehensively developed across the country.

There are more than 2,400 universities (most universities are adjacent or close to each other) in China. Party construction in colleges and universities is served as typical "unit system party construction”. Regional party construction can not be separated from active involvement of the region. However, not all practices with regional party construction are participated by colleges and universities. Colleges and universities are typical representatives of regional organization. Practice of regional party construction widely coopered or jointly participated by colleges and universities has already widely developed. Chen Xin, president of Guangdong University of Technology, was directly elected as deputy director of Cailiao Community Residents Committee of Huanghuagang Street, Yuexiu District, Guangzhou City in March, 2011. Viewed from existing research results, there are many researches on party construction in colleges and universities and communities. For instance, Zhang Chun and others proposed that colleges \& universities and communities were two basic units of grass-roots party construction and they had respective advantages and disadvantages. To exploit the advantages to the full, avoid deficiencies and realize complementary advantages is of great advantage for the promotion of the work of party construction in both colleges \& universities and communities. The most marked feature of these researches is to regard colleges \& universities and communities as two independent subjects, analyze current situation, find out relevant issues and propose suggestions, so as to give full play to functions of these subjects respectively.

\section{Principles for Regional Party Construction in Colleges and Universities}

\section{Mutual benefit and reciprocity}

Colleges \& universities and communities have strong cooperative willingness. While carrying on gradually weakened control force of "unit system" society toward people and a great deal of increased specific businesses, communities are also in an awkward situation of unsubstantial human resources, social resources and common resources by being confronted with such practical problems as increased new economic and new social organizations, diversified appeals of social members, difficult community governance, complex composition of community party members, difficult management of floating party members and obvious regionalization of community party construction. To improve the quality of talent cultivation, it is necessary for colleges and 
universities to win supports for regional communities. Colleges and universities are perplexed all the time by stalls \& food safety around the campus, safety management of residential house renting and outside school accommodation of students, real estate and safety management of non-teaching and administrative staff residents in the campus and outstanding home-based care for retired staff. Gradually intensified “community resident consciousness” of college teachers and students also formed more expectations to regional communities.

Both colleges \& universities and communities have concerns during cooperation. Colleges \& universities worry about unilateral payout and too heavy responsibilities, deviation of educational orientation as well as the failure of community voluntary service to reach relevant requirements of professional practice. College students and teachers lack the cognition of community cooperation. They thought that community cooperation was not highly correlated with their career development and academic completion. Communities always thought that payout was "of course" for colleges and universities. Communities failed to solve practical problems. Moreover, communities' investment into labor, finance and material was instable. Community residents pay much attention to practical issues. They thought that activities developed by colleges and universities and college students and teachers were indirectly correlated with themselves.

\section{Advantage convergence}

According to subdivision of organizers, China's colleges and universities are managed by municipality and annexed territory at the same time. Party organization construction in colleges and universities should implement educational policies of the Party, adhere to moral composition and talent cultivation and centre on the promotion of all-round development of morality, intelligence physique and aesthetic. Colleges and universities have such advantages as rich human resources, abundant intellectual resources, advanced cultural resources and cutting-edge information resources. In the participation of regional party construction, colleges and universities are mainly responsible for contact with community party organizations. Due to difference between community party organizations and college party organizations in management system, functional orientation, resources allocation method and advantage presentation mode, their role modes are nationally different. Due to functional orientation in social management, community (street) party organization naturally becomes the core in regional party construction, and gives play to its advantages of being familiar with various aspects in the region. In the process of regional party construction, it is not recommended for colleges and universities to try to become the core. Instead, colleges and universities should make positive orientation, give full play to the service function and properly act as an "active participant" or a “main participant”. 


\section{Practice orientation}

The aim of regional party construction is to overcome deficiencies of traditional "unit system party construction" and give proper play to the social integration function of a primary party organization. There are many difficulties in the process of practice. If the core is instable, it is very difficult to continuously shoulder the function of centralization and coordination. Moreover, the promotion of work relying on administrative means will result in unfavorable effects. The issue is rooted in gradually weakened resource control and allocation power of grass-roots party organization. "If the party organization continues to substitute the party for the government or substitute the party for the community like before, its space of giving a role by administrative power will be greatly narrowed. To realize its political function, the Party must give full play to its function of non-power influence. Nowadays, the best presentation mode of such non-power influence is service.” Therefore, regional party construction in colleges and universities should begin with weak places and positively adapt to realistic development needs. To adhere to practice guidance, we must center on common needs, common benefits and common targets of all organizations, groups and individuals in the region, highlight "service" themes and principal lines and perform more works to meet needs, expand benefits and realize targets.

III. Approaches for Regional Party Construction in Colleges and Universities

\section{Establish regional service center}

The core function of regional party construction is to improve service capability and level. Colleges and universities should positively establish or cooperate with communities to establish party member service center, open such center to all party members and the masses in the region and take this as an important pattern to properly perform the service function of colleges and universities. Relying on the service center, colleges and universities should also develop consultation of policies and regulations, planning for the work of party construction, skill training, technical guidance, assistance of right protection and assistance of employment \& innovation programs for all kinds of organizations and members in the community, so as to solve practical problems. Besides, the center should also increase the service and support degree of vulnerable groups, take poor families, laid-off and unemployed workers and idle teenagers as key service objects, try the best to perform good deeds and solve difficulties for them, go deep into communities to develop various voluntary activities, and directly serve to the improvement to life quality of residents. Moreover, the center should also concern and spiritually and materially love left-behind elderly and children. Colleges and universities with favorable conditions should also rely on social work, pension service and other disciplinary students and teachers to establish pension health service stations or provide package service. Colleges and universities with mature conditions should also strive for becoming objects of government pension service procurement. 


\section{Develop information-based party construction}

To utilize information technology to forge a more scientific and more convenient party construction platform is the optimal approach used to break horizontal obstruction of all kinds of organizations and party organizations in the region. At the same time, such platform is also the development tendency. In the process of practice, it is universal for such issues as defectively tight coincidence between informatization and grass-roots party organization construction, insufficient popularization of the use of information technology means, single channels of popular will appeal and separation of the masses' evaluation from cadre assessment. Therefore, we should make great efforts to promote the construction of electronic party affairs, closely integrate information construction of party construction with grass-roots party organization construction and closely combine with party construction affairs by unifying standards, integrating resources, optimizing business flows and sharing network service, promote the scientific transformation of party construction, forge a regional party construction cloud platform, properly construct cloud foundation platform, party affair management, mass line, opening of the party affairs, party member education, party member service, online branch, party construction communication, examination and evaluation, information comprehensive management, client-side management and other modules, and positively promote the establishment of online e-branch, party construction microblog group, QQ group, online Party representative work room, online party member meeting, network public recommendation \& direct election, party member congress hall and other new patterns and new carries presenting the characteristics of information times. For instance, online e-branch can make up deficiencies of traditional party branch construction and organizational life mode. Moreover, it is also beneficial for further strengthening daily learning exchange of party members. Furthermore, it is even helpful for the establishment of college party organizations and community party organizations, connection \& communication between party members of college teachers and students and community party members, overcoming difficult face-to-face communication of regional party members and other issues, and forging a new state of regional party construction.

3. Develop cultural and recreational activities

Colleges and universities should utilize their cultural advantages to positively develop community cultural construction and improve the level of community cultural construction. Moreover, colleges and universities should also combine disciplinary advantages to develop public benefit activities such as legal consulting, psychological counseling and psychological health education, develop keep-fit exercises, advocate positive and healthy lifestyle, and develop environmental protection publicity and other vivid and interesting activities. In addition, colleges and universities can also hold all kinds of artist programs and recreational activities, perform sketches, 
comic dialogues, songs, dancing and other activities reflecting time spirits for communities, and give material benefits to community residents through these activities. College participants are trained. At the same time, these activities are also beneficial for advocacy of constructing new civilized and harmonious life.

4. Participate into community governance

Community plays a more and more important role in urban work. A large number of new economic organizations and new social organizations need to community party organizations to strengthen party construction in these organizations and continuously expand the coverage of the Party in urban works. More and more "unit persons" gradually transformed into "social persons". Retirees, unemployed persons, home-based old people and floating personnel increased. Material and cultural needs of community residents increasingly presented the tendency of multi-level and diversification. It is necessary for community party organizations to positively change management style into governance. The condition is still immature for colleges \& universities and regional communities to implement unified governance model. Due to historical reasons, it is common for the irrespective phenomenon of teaching area and staff accommodation area in most Chinese colleges and universities. In recent years, considerable housing-reformation houses and collected-funds houses have been changed into commercial residential buildings and entered into the market for circulation. Residents in the campus have already presented the concurrent state of campus staff and non-campus staff. The past campus management basically had radical change in terms of the coincident state of staff management, but it obviously can not be finished by colleges and universities to manage all campus residents and provide relevant services. Colleges and universities should utilize their governance experiences to help communities to make innovation in governance mode, enhance the leadership, coordination and service function of community party organizations, make community development to be more standard and scientific and more adaptive to production and life needs of community residents.

IV. Guarantee of Regional Party Construction in Colleges and Universities

1. Innovate the setting of party organizations

The setting of regional party construction must adhere to the establishment of new communities characterized with ordered management, complete service, beautiful environment, friendly affection, mutual assistance, civilization and harmony and the provision of strong organizational guarantee. The purpose of innovation to party construction operating mode is to make organs, public institutions, small and micro businesses, schools, scientific research institutions, new economic and new social organization and party organizations established in the region to take actions and positively participate into regional party construction. We should intensify the consciousness of joint construction, build a joint construction atmosphere for regional party 
construction, find out all organizations and party members in the region, make them become from "spectators" into “insiders", mainly construct a learning improvement platform for community Party members and cadres and erect the social practice platform for college students and teachers, and the community cultural construction and college campus culture construction platform.

2. Structure assessment and evaluation mechanisms

We should establish an examination and evaluation mechanism based on long-term interests and improvement to the masses' satisfaction. The examination and evaluation mechanism perfected in regional party construction includes subject, standard, procedure, feedback and other contents of examination and evaluation. Regional party organizations, party members and the masses are responsible for evaluation, so as to realize basic evaluation for regional party construction in a certain period of time, reflect party construction works in a scientific way and evaluate cooperative effects of colleges \& universities and communities. Value goal should be taken as a factor to realize win-win of several subjects. However, it is not the only indicator. Pursuit of regional participants and several subjects for practical interests can not be avoided all the time. The present problem is to lay emphasis on short-term effect and practical economic interests. To make innovation to the evaluation method, we must set up the evaluation concept and mode of emphasis on long-term and social benefits and seeking for long-term effects. The central task of colleges and universities is talent cultivation; while the central task of communities is to improve living standards and happiness indexes of residents, jointly promote regional party construction and improve the social integration capability of grass-roots party organizations. All methods and attempts beneficial for the realization of our targets should become programs with "awarded marks" in examination and evaluation. The establishment of such examination and evaluation mechanism can make all parties not to pay much attention on respective payout in the cooperation process. Instead, they are made to properly compromise, open their working areas, establish effective long-term cooperative mechanisms, and realize multi-win cooperation.

\section{Conclusion}

Regional party construction in colleges and universities is a piece of work with strong practice. Based on carrying forward advantages of "unit system party construction”, colleges and universities should promote "regional party construction”, positively guide regional organizations to participate into regional party construction, and establish a multi-subject collaborative mechanism, so as to give play to demonstration effect of promoting regional party construction.

\section{Acknowledgments}

This paper is the key research project of Sichuan Provincial Department of Education in 2010: Research on Operational Mode of a Learning Party Organization Jointly Constructed by Colleges and Universities and Communities (project No.: 10SA042). 


\section{References:}

[1] Song Lamei, Regional Party Construction should Embody the Spirit of Democracy and Equality [N], Shenzhen Special Zone Daily, 2010.11.16;

[2] Hu Jin, Grass-roots Party Construction and Construction of Harmonious Community: Nanshan's Practice Approach and Theoretical Innovation [M], Beijing: Social Sciences Academic Press, 2010.8. 